\title{
Influences of Biological Control on Damping Off Diseases of Faba beans as well as Physico-Chemical and Technological Properties
}

\section{Ghada A. Alfauomy ${ }^{1}$ and Marwa A.M. Atwa ${ }^{2}$}

\author{
${ }^{1}$ Crops Technology Research Department, Food Technology Research Institute, Agricultural Research \\ Center, Giza, Egypt \\ ${ }^{2}$ Legume and Forage Diseases Research Department, Plant Pathology Research Institute, Agricultural \\ Research Centre, Giza, Egypt \\ Received: 20 Oct. 2020 / Accepted 05 Dec. 2020 / Publication date: 10 Dec. 2020
}

\begin{abstract}
Faba bean seeds are the most important legumes in terms of consumption, for its positive nutritional properties and the most important diseases of Faba bean seeds are damping off. The field experiments was carried out during the 2017- 2018 and 2018-2019 seasons to study the effect of the biocontrol agents as well as Rizolex $T$ on the incidence of Faba beans damping off disease. The growth parameters, yield and its quality parameters of Faba bean plants were also, studied. The cultures of Paenibacillus polymyxa, Pseudomonas fluorescens and Bacillus megaterium bacteria and the Trichoderma viride, Trichoderma. harzianum fungi were used. The results exhibited that, the highest percentage of preemergence damping off reduction, the maximum plant height and the maximum seeds weight per plant were recorded with Rizolex T and P. polymyxa followed by B. megaterium and T. harzianum treatments. Significantly increases in the percentage of survived plants compared with the control were found in all treatments. Number of branches, and number of pods per plants were the highest in the Rizolex $T$ treatment. Quality parameters of the faba bean crops resulted, such as protein, protein digestibility and minerals ( $\mathrm{Fe}$ and $\mathrm{Zn}$ ), as well as, total flavonoid and antioxidant activity evaluations were significantly increased in $P$. polymyxa, B. megaterium followed by Rizolex T compared with control samples. Technological evaluation of density, ratio between cotyledons and seed coats, as well as, water absorption, hydration coefficients and swelling coefficients after soaking and cooking were studied and showed high levels in Faba beans treated with P. polymyxa, B. megaterium and Rizolex T. Also, high level of cookability (stewing) and sensory characteristics were detected in Faba beans treated with $P$. polymyxa, B. megaterium and Rizolex T compared with other treatments and control.
\end{abstract}

Keywords: Faba beans, Damping off, Biocontrol agents, Rizolex T, Hydration coefficients, Swelling coefficients

\section{Introduction}

Legumes have beneficial health implications related to their nutritional properties. They are an important source of macronutrients, containing almost twice the amount of proteins compared to cereal grains. Faba beans (Vicia faba L.) is one of the important winter legume crop grown in northern eastern of Africa i.e. Egypt, Sudan and Ethiopia (Multari et al., 2015). It has been used as a meat extender or as a substitute due to its high protein contents, it is also, comparatively high in lysine, which is an essential amino acid for human (Robinson et al., 2019).

Faba bean seeds are an excellent nitrogen fixer which makes it suitable for food and feed production. The quality and yield of Faba bean seeds are affected by soil type, climatic conditions and agronomic factors. The key biotic factors responsible for yield loss in Faba bean seeds are fungal diseases (Barłóg et al., 2018). Crop losses due to diseases can reach $15 \%$ or even $80 \%$ in species of the Fabaceae family (Horoszkiewicz-Janka et al., 2013).

Faba bean seeds damping off caused by Rhizoctonia solani Kühn and Fusarium solani Mart are considered the most destructive diseases. However, roots rot diseases caused by Rhizoctonia solani Kühn is a major cause of yield instability and losses for Faba beans production in most areas of the world. Plant pathologists make great efforts to reduce the use of synthetic fungicides and to improve the use of alternative management strategies to control soil-borne pathogens. Acquired resistance that increases plant resistance to subsequent pathogen attack, by using biotic (microorganisms) seemed, to

Corresponding Author: Ghada A. Alfauomy, Crops Technology Research Department, Food Technology Research Institute, Agricultural Research Center, Giza, Egypt. 
be one of alternatives to substitute for decreasing the use of fungicides in plant disease control (Walters et al., 2013).

Recently, biological control has intensively been studied by many researchers throughout the world. Bio-inoculants containing living cells of microorganisms could be an effective alternative for chemicals in food production (O'Callaghan, 2016).

Paenibacillus polymyxa and Pseudomonas fluorescens are known for their ability to produce antimicrobial metabolites and hydrolytic enzymes, such as $\beta-1,3$-glucanase, chitinase, and protease, which are considered key enzymes in control of fungal plant diseases. So, application of Paenibacillus polymyxa in seeds can be used to manage pre- and post-emergence damping off in plants. However, Bacillus megaterium is a potential bacterial biocontrol agent against Rhizoctonia solani (Zhang et al., 2016).

The species of the genus Trichoderma, which contain a group of plant growth-promoting fungi, can colonize the intercellular parts of plant roots and stimulate systemic resistance in all parts of the plant, the actions of these fungi suppress some plant diseases by direct mycoparasitism or antibiosis, as well as indirect induced resistance (Sharma and Sain, 2004).

Faba bean seeds are a potential source of dietary fiber and it has a high content of essential mineral elements. Malnutrition mineral affects millions of people all over the world. Faba bean seeds have higher concentrations of minerals (e.g., $\mathrm{Fe}, \mathrm{Zn}, \mathrm{K}$ and $\mathrm{Mg}$ ) than some other cereal grains (White and Broadley, 2009).

Phenolics compounds are plant secondary metabolites and have important roles in pigment biosynthesis. They also, provide a scaffolding support and a structural integrity to plants (Bhattacharya et al., 2010). Plants need these compounds for pigmentation, growth, reproduction, resistance to pathogens, repel or kill many microorganisms, defaces or even subvert them to their own advantage (Boudet, 2007).

Phenolic compounds as well as flavonoids are well-known as antioxidant activities agents related with their ability to scavenge free radicals and break radical chain reactions. Likewise, they have several important bioactive agents that have been attractive because of their benefits for the human health (Tungmunnithum et al., 2018).

The antioxidant properties of Faba bean extracts are related to total phenolics and flavonoids contents. Differences in total phenolics and flavonoids were observed for different genotypes collected during three different growing stages. Higher contents of total phenolics and flavonoids were found during vegetative and reproductive stages, which also showed the highest antioxidant activity (Boukhanouf et al., 2016).

Faba bean seeds can be fresh consumed (green stage) or after cooking. Their polyphenol profiles are affected by processing such as soaking, sprouting, freezing, boiling, pressure cooking and steaming.

Soaking, boiling and autoclaving caused losses in phenolic compounds and antioxidant activities due to leaching of these compounds into the soaking and cooking medium. Boiling was shown to be a better method than autoclaving in keeping phenolic compounds, and it is suggested that home-cooked Faba beans may contain higher levels of phenolic content than industrially processed Faba beans (Siah et al., 2014). Even sprouting, a process involving germination and drying of legume seeds was found to decrease total polyphenol content and was associated with improvements in the nutritive value in sprouted seeds. Due to the aforementioned inhibitory, effect of tannins and other anti-nutritional factors on mineral bioavailability, all the treatments (soaking, germination and boiling) significantly improved in vitro availability of minerals and protein digestibility (Luo and Xie, 2014).

The aim of this study was to investigate the effect biotic treatments for controlling damping off diseases and estimate the quality of the Faba bean seeds and its technological characteristics.

\section{Materials and Methods}

\section{Materials}

Faba bean seeds (Vicia faba L.), cultivar Misr 1 were obtained from the Legumes Res. Dept., Field Crops Res. Inst., ARC, Giza, Egypt. Apparently healthy uniformity seeds of Faba beans were surface disinfected by immersing in a sodium hypochlorite solution (1\%) for $2 \mathrm{~min}$, and several times washed with sterilized water, then left to dry on screen cloth with paper towels to absorb the excess water at the room temperature for approximately two hour. 


\section{Biotic inducers}

The cultures of the Paenibacillus polymyxa, Pseudomonas fluorescens, previously isolated by the authors (Shehata et al., 2006), and Bacillus megaterium bacteria were activated on fresh slants. After $24 \mathrm{hr}$ bacterial isolates were transferred to many erlenmeyer flasks $(250 \mathrm{ml})$ with $50 \mathrm{ml}$ of a nutrient yeast dextrose broth (NYDB) medium for P. polymyxa and B. megaterium and $50 \mathrm{ml}$ of a King's medium broth (KMB) for $P$. fluorescens. The flasks were placed on a rotary shaker to grow at $120 \mathrm{rpm}$ for $66 \mathrm{hr}$ at $24^{\circ} \pm 1^{\circ} \mathrm{C}$, after growth of bacterial isolates, the liquid cultures media were then centrifuged under cooling $\left(4^{\circ} \mathrm{C}\right)$ at $10000 \mathrm{rpm}$ for $10 \mathrm{~min}$. Then, the disinfected Faba bean seeds were soaked in a supernatant for 20 minutes, then spread on screen cloth. The coated seeds were air-dried for $15 \mathrm{hr}$ until planting time.

Trichoderma harzianum and Trichoderma viride fungi were collected by Plant Pathol. Dept., Fac. of Agric., Ain Shams Univ. and identification according to Rifai (1969). Formulation was prepared by growing the fungus in glass bottles $(500 \mathrm{ml})$ containing 100 gram sterilized sorghum grains medium according to Rini and Sulochana (2007). Air dried fine grinded sorghum grains, which contained 3.9x $10^{9}$ (CFU) of T. harzianum and T. viride, was used to coat the disinfected Faba bean seeds moistened with $1 \%$ methyl cellulose in sterile distilled water as a sticker, then the coated seeds were air-dried for $15 \mathrm{hr}$ until planting time (Tewari and Bhanu, 2004).

\section{Fungicide treatment:}

Seed dressing was carried out to the disinfected Faba bean seeds by applying the Rizolex T $50 \%$ WP [(Tolclofos-methyl-thiram), Sumitomo Chemical Company Ltd.] at the recommended dose ( $3 \mathrm{~g} / \mathrm{kg})$ to the $1 \%$ methyl cellulose (as a sticker), moistened seeds were packed in polyethylene bags and shaking well, to ensure even distribution of the fungicide, according to the recommendations of the Egyptian Ministry of Agriculture and Land Reclamation.

\section{Root-nodule bacteria treatment}

Formulation of Rhizobium leguminosarum biovar Viciae (Faba beans), was obtained from Biofertilizers Production Unit, Soils Water and Environment Research Institute, Agricultural Research Center, Giza, Egypt and it was used to inoculate field soil. Rhizobium formulation was mixed with approximately $50 \mathrm{~kg}$ of moistened fine sandy soil and added to field soil during planting at a rate of 800 g Rhizobium formulation / Feddan, according to the recommendations of the Egyptian Ministry of Agriculture and Land Reclamation.

\section{Disease assessment}

The disease incidence (DI) \% was determined by recording pre-emergence damping off, postemergence damping off and the percentage of survived plants at 15, 30 and 45 days after planting, respectively according to the following formulas (Atwa, 2016):

$$
\begin{gathered}
\text { Pre-emergence } \%=\frac{\text { Total No. of un-germinated seeds }}{\text { Total No. of planted seeds }} \times 100 \\
\text { Post-emergence } \%=\frac{\text { Total No. of rotted seedlings }}{\text { Total No. of planted seeds }} \times 100 \\
\text { Survived seedlings } \%=\frac{\text { Total No. of survived seedlings }}{\text { Total No. of planted seeds }} \times 100
\end{gathered}
$$

Reduction or increasing \% over the infected control was also calculated according to the following formula:

$$
\text { Reduction or Increasing } \%=\frac{\text { DI of Control }- \text { DI of treatment }}{\text { DI of Control }} \times 100
$$

\section{Field experiments}

The field experiments was carried out during the two winter growing seasons 2017- 2018 and 2018-2019 at Giza Agricultural Research Station, Giza Governorate, Egypt, in field known to have a root 
rot history, in order to investigate the effect biotic treatment for controlling damping off. In the control treatment, the disinfected Faba beans were soaked in distilled water. The field trial (28 plots) was designed in a complete randomized block (four replicates). Each plot $\left(10.50 \mathrm{~m}^{2}\right)$ was consisted of five rows; each row was $3.5 \mathrm{~m}$ length and $0.6 \mathrm{~m}$ width. All treatments were sown in hills $20 \mathrm{~cm}$ apart on both sides of the row ridge with one seed/hill. Calcium super-phosphate $\left(15 \% \mathrm{P}_{2} \mathrm{O}_{5}\right)$ at $150 \mathrm{~kg} / \mathrm{Feddan}$ was added on rows during the soil preparation. Potassium sulphate $\left(48 \% \mathrm{~K}_{2} \mathrm{SO}_{4}\right)$ at $50 \mathrm{Kg} / \mathrm{Feddan}$ was applied as soil application at the first irrigation after planting. Ammonium sulphate $(20.5 \% \mathrm{~N})$ at a rate of 75 $100 \mathrm{~kg} /$ Feddan was added at the planting time as a starter dose of nitrogen. All recommended agricultural practices were monitored according to the recommendations of the Egyptian Ministry of Agriculture and Land Reclamation. The treatments were as follows: (1) T.viride, (2) T. harzianum, (3) P. flouresence, (4) B. megaterium, (5) P. polymyxa, (6) Rizolex T and Water (control). The disease incidence (DI) \% was determined as mentioned before. Random samples of twenty Faba bean plants were collected (from the inner rows) at the harvest stage from each plot. Plant growth parameters of plant height (cm), number of pods per plant, number of branches, seed weight per plant and weight of one hundred seeds were recorded as well as seed yield Ton/Feddan were calculated.

\section{Technological characteristics: (on 2018-2019 seasons)}

\subsection{Preparation of seeds for soaking and cooking}

Faba bean seeds were manually cleaned from broken or damaged seeds, stones, dust and other foreign materials. The cleaned Faba bean seeds were soaked for $12 \mathrm{hr}$ at the room temperature $\left(30 \pm 2^{\circ} \mathrm{C}\right)$ in tap water. A ratio of 1: 4 (w/v) seeds to water was used according to Avila et al., (2015), water absorption was determined after soaking.

Cooking: seeds were cooked in oven for $12 \mathrm{hr}$ at $100^{\circ} \mathrm{C}$. After cooking the following measurements were determined in cooked seeds according to the method of Fahmy et al. (1996).

Water absorption of soaking and cooking Faba bean seeds were calculated by Fahmy et al. (1996) as follows:

$$
\begin{aligned}
& \text { Water absorption (\%) of soaking }=\quad \frac{\text { Seeds weight after soaking }- \text { Seeds weight before soaking }}{\text { Seeds weight before soaking }} \times 100 \\
& \text { Water absorption (\%) of cooking }=\frac{\text { Seeds weight after cooking }- \text { Seeds weight before cooking }}{\text { Seeds weight before cooking }} \times 100
\end{aligned}
$$

\subsection{Hydration coefficient of Faba bean seeds} (1988).

Hydration coefficient of Faba bean seeds soaking was calculated according to El-Refai et al.,

$$
\begin{aligned}
& \text { Hydration coefficient (\%) of soaking }=\frac{\text { Seeds weight after soaking }}{\text { Seeds weight before soaking }} \times 100 \\
& \text { Hydration coefficient }(\%) \text { of cooking }=\frac{\text { Seeds weight after cooking }}{\text { Seeds weight before cooking }} \times 100
\end{aligned}
$$

7.3. Swelling coefficient of Faba bean seeds: Swelling coefficient of soaking and cooking Faba bean seeds calculated according to El-Refai et al., (1988).

$$
\begin{aligned}
& \text { Swelling coefficient (\%) of soaking Faba beans }=\frac{\text { Seeds volume after soaking }}{\text { Seeds volume before soaking }} \times 100 \\
& \text { Swelling coefficient (\%) of cooking Faba beans }=\frac{\text { Seeds volume after cooking }}{\text { Seeds volume of before cooking }} \times 100
\end{aligned}
$$

\subsection{Water soluble solids}

After cooking, the solution containing soluble material was poured into a porcelain pot placed in an oven at $60^{\circ} \mathrm{C}$ until all the water was evaporated (Fahmy et al., 1996). The pot was weighed and water soluble solids calculated as follows: 
Water soluble solids $(\%)=\frac{\text { Weight of pot after drying }- \text { Weight of empty pot }}{\text { Initial weight of seeds }} \times 100$

\subsection{Stewing \% (cook ability)}

The ability of seeds to be cooked was measured by means of using the normal press of fingers and comparing between the cooked seeds for their hardness (Ismail et al., 2007). Stewing percentage is calculated as follows:

$$
\text { Stewing }(\%)=\frac{\text { Initial number of seeds }- \text { non stewing seeds number }}{\text { Initial number of seeds }} \times 100
$$

\section{Physical characteristics}

\subsection{Ratio of cotyledons to seed coat}

The seeds were emergent in water for $12 \mathrm{hr}$, after that, weight the cotyledons and the seed coat of soaked Faba beans and calculate the ratio of cotyledons to seed coat (Osman et al., 2010).

\subsection{Determination of color}

The color of Faba bean samples were measured using a hand-held Tristimulus Reflectance Colorimeter, Minolta chromammeter (CR-400 model, Konica Minolta, Japan) using different color parameters $L$ (lightness with $L=100$ for lightness, and $L=$ zero for darkness), $a$ [(chromaticity on green $(-)$ to red $(+)], b[($ chromaticity on a blue $(-)$ to yellow $(+)]$. Reported values are the means of triplicate determinations.

\section{Chemical analysis:}

\subsection{Chemical composition}

The contents of moisture, protein, crude fiber, ash and fat of Faba bean seeds $(n=3)$ were determined following the official methods of analysis (AOAC, 2012). In vitro protein digestibility was determined according to Akeson and Stahmann (1964). Total carbohydrates were calculated by difference [100-(Protein + Fat + Ash + Crude fiber)]. Minerals content in Faba bean seeds were determined according to AOAC (2012) by using Agilent Technologies, Microwave Plasma Atomic Emission Spectroscopy (MP-AES 4210).

\subsection{Determination of total phenols content (TP)}

Total phenols were estimated by the Folin-Ciocalteu method reported by Singleton and Rossi (1965).

\subsection{Determination of total flavonoids content (TF)}

The amount of total flavonoids in the extracts was measured spectrophotometrically following the method reported by Zhishen et al. (1999).

\subsection{DPPH radical scavenging activity}

The antioxidant activity of Faba bean samples was determined based on the radical scavenging ability in reacting with a stable DPPH free radical solution according to Brand-Williams et al. (1995).

\subsection{Determination of tannins content}

Tannin content was estimated using the vanillin $\mathrm{HCl}$ method (Price et al., 1978).

\section{Sensory evaluation of cooked Faba beans}

Organoleptic characteristics (color, texture, taste, odor and overall quality) of Faba beans were evaluated by 10 panelists from Food Technology Research Institute, Agricultural Research Center, Giza, Egypt. A numerical hedonic scale, which ranged from 1 to 10 ( 1 is very bad and 10 for excellent), was used for sensory evaluation (Larmond, 1977).

\section{Statistical analysis}

Randomized blocks design (RBD) were conducted in field experiment. The obtained data were subjected to computer statistical software (ASSI STAT) originated by Silva and Azevedo (2009). While 
for quality and technology traits, the collected date were statistically analyzed for mean values and standard deviation and are reported using Costat statistical software according to Steel and Torrie (1980). The obtained data were subjected to one-way analysis of variance (ANOVA) at $(\mathrm{P} \leq 0.05)$ followed by Duncan's new multiple range tests to assess differences between samples mean.

\section{Results and Discussion}

\section{Field experiments}

\subsection{Effect of some biocontrol agents on the incidence of Faba beans damping off disease}

In these experiments, the effect of treatments by different biocontrol and the chemical fungicide (Rizolex T) agents on damping off incidence and survived plants of Faba beans under field conditions at Giza, Agricultural Research (during 2017/2018 and 2018/2019 seasons) were studied. Results in Table (1) exhibited that all the tested treatments significantly decreased the percentages of pre and postemergence damping off compared with untreated control sample. The highest percentage of preemergence damping off reduction over the control was obtained from treatments with Rizolex $\mathrm{T}$ and $P$. polymyxa. Also, results showed that all the tested treatments significantly increased the percentage of survived plants compared with the control.

He et al., (2007) found that, P. polymyxa is known for its ability to produce antimicrobial compounds. More than that, $P$. polymyxa strains are capable of producing several hydrolytic enzymes, including $\beta 1,3$-glucanases and chitinases which are considered key enzymes in control of fungal plant diseases (Jung et al ., 2003 and Raza et al., 2009).

Table 1: Effect of some chemical and biocontrol agents as seed treatments on the percentage of damping off disease of Faba bean plants grown under field conditions at Giza Agricultural Research during winter growing 2017-2018 and 2018-2019 seasons

\begin{tabular}{|c|c|c|c|c|c|c|}
\hline \multicolumn{7}{|c|}{$2017-2018$} \\
\hline \multirow{3}{*}{ Treatments } & \multicolumn{4}{|c|}{$\begin{array}{c}\text { Damping off } \\
\end{array}$} & \multirow{3}{*}{$\begin{array}{c}\text { Survived } \\
\text { plants } \\
(\%)\end{array}$} & \multirow{3}{*}{$\begin{array}{c}\text { Increasing } \\
(\%)\end{array}$} \\
\hline & \multicolumn{2}{|c|}{ Pre-emergence } & \multicolumn{2}{|c|}{ Post- emergence } & & \\
\hline & $\begin{array}{c}\text { Incidence } \\
(\%)\end{array}$ & $\begin{array}{c}\text { Reduction } \\
(\%)\end{array}$ & $\begin{array}{c}\text { Incidence } \\
(\%)\end{array}$ & $\begin{array}{c}\text { Reduction } \\
(\%)\end{array}$ & & \\
\hline$T$. viride & $12.5^{\mathrm{b}}$ & 55.4 & $2.5^{\mathrm{b}}$ & 43.2 & $85.0^{\mathrm{ab}}$ & 25.7 \\
\hline T. harzianum & $12.1^{\mathrm{b}}$ & 56.8 & $2.7^{b}$ & 36.4 & $85.2^{\mathrm{ab}}$ & 26.0 \\
\hline P. flouresence & $11.3^{\mathrm{b}}$ & 59.4 & $2.6^{\mathrm{b}}$ & 41.0 & $86.1^{\mathrm{ab}}$ & 27.4 \\
\hline B.megaterium & $10.3^{b}$ & 63.2 & $2.3^{\mathrm{b}}$ & 47.7 & $87.4^{\mathrm{a}}$ & 29.3 \\
\hline P. polymyxa & $9.7^{b}$ & 65.4 & $2.0^{\mathrm{b}}$ & 54.5 & $88.3^{\mathrm{a}}$ & 31.0 \\
\hline Rizolex T & $6.5^{c}$ & 76.8 & $1.6^{\mathrm{b}}$ & 63.6 & $91.8^{\mathrm{a}}$ & 35.8 \\
\hline Control & $28.0^{\mathrm{a}}$ & 0.0 & $4.4^{\mathrm{a}}$ & 0.0 & $67.6^{\mathrm{c}}$ & 0.0 \\
\hline \multicolumn{7}{|c|}{ 2018-2019 } \\
\hline T. viride & $13.1^{\mathrm{b}}$ & 56.6 & $2.6^{\mathrm{b}}$ & 49.0 & $84.3^{\mathrm{b}}$ & 30.3 \\
\hline T. harzianum & $12.6^{\mathrm{b}}$ & 54.6 & $2.7^{b}$ & 47.1 & $84.7^{b}$ & 31.0 \\
\hline P. flouresence & $11.6^{\mathrm{b}}$ & 61.6 & $3.1^{\mathrm{b}}$ & 39.2 & $85.3^{\mathrm{b}}$ & 31.8 \\
\hline B.megaterium & $10.9^{b c}$ & 64.0 & $3.0^{b}$ & 41.2 & $86.1^{\mathrm{ab}}$ & 33.1 \\
\hline P. polymyxa & $10.1^{b c}$ & 66.5 & $2.8^{b}$ & 45.1 & $87.1^{\mathrm{ab}}$ & 34.6 \\
\hline Rizolex T & $7.4^{\mathrm{c}}$ & 75.5 & $2.7^{b}$ & 47.1 & $89.9^{\text {a }}$ & 39.0 \\
\hline Control & $30.2^{\mathrm{a}}$ & 0.0 & $5.1^{\mathrm{a}}$ & 0.0 & $64.7^{c}$ & 0.0 \\
\hline
\end{tabular}

Values are the average of 3 experiments. Mean values (within the same column) followed by different superscripts are significantly different at the $5 \%$ level.

\subsection{Effect of some inducers on growth parameters and yield of Faba bean plants}

Under the tested field conditions, bioagents treatments significantly improved growth and yield parameters compared to the untreated control treatment as presented in Table (2). The plant height was affected by seed treatments with different biocontrol agents, all treatments at two growing seasons significantly increased the plant height compared with untreated control. The maximum plant height was recorded with Rizolex T and P. polymyxa treatments followed by B. megaterium and T. harzianum treatments and it differed from rest of all treatments.

Number of branches per plant was affected by seed treatments with some different biocontrol agents. All the biocontrol agents at Giza Agricultural Research at two seasons significantly showed an 
increase in number of branches as compared with untreated control. Highest significant increase in the number of branches per plant was recorded with Rizolex T treatment.

All treatments significantly increased number of pods per plant as compared with untreated control. The maximum number of pods per plant was recorded with Rizolex $\mathrm{T}$ treatments which significantly differed from other treatments, also increased seed weight per plant in two seasons as compared with untreated control. At 2017-2018 growing seasons, the maximum seed weight per plant was recorded with Rizolex T followed by P. polymyxa, B. megaterium and T. harzianum. Meantime, there were no significant differences among the treatments at 2018-2019 growing seasons.

Table 2: Effect of some chemical and biotic inducers as seed treatments on some growth parameters of Faba bean plants grown under field conditions at Giza Agricultural Research during winter growing 2017-2018 and 2018-2019 seasons

\begin{tabular}{|c|c|c|c|c|c|c|}
\hline \multicolumn{7}{|c|}{$2017-2018$} \\
\hline Treatments & $\begin{array}{l}\text { Plant height } \\
\text { (cm) }\end{array}$ & $\begin{array}{l}\text { Number of } \\
\text { branches/ } \\
\text { plant }\end{array}$ & $\begin{array}{l}\text { Number of } \\
\text { pods/ plant }\end{array}$ & $\begin{array}{c}\text { Seeds } \\
\text { weight/ } \\
\text { Plant } \\
\text { (g) }\end{array}$ & $\begin{array}{c}100 \text { seeds } \\
\text { weight } \\
\text { (g) }\end{array}$ & $\begin{array}{c}\text { Seeds yield } \\
\text { (ton/fed) }\end{array}$ \\
\hline$\overline{T .}$ viride & $105.8^{b c}$ & $2.9^{b}$ & $16.8^{b c}$ & $31.5^{\mathrm{c}}$ & $73.4^{b}$ & $1.250^{\mathrm{c}}$ \\
\hline T. harzianum & $106.8^{b c}$ & $3.0^{\mathrm{b}}$ & $17.2^{\mathrm{b}}$ & $32.0^{\mathrm{b}}$ & $73.6^{\mathrm{b}}$ & $1.270^{\mathrm{c}}$ \\
\hline P. flouresence & $100.1^{\mathrm{c}}$ & $2.8^{b}$ & $16.4^{\mathrm{c}}$ & $30.9^{c}$ & $71.8^{b}$ & $1.260^{\mathrm{c}}$ \\
\hline B. megaterium & $108.5^{b}$ & $3.2^{b}$ & $16.8^{\mathrm{bc}}$ & $32.4^{b}$ & $73.6^{b}$ & $1.298^{\mathrm{c}}$ \\
\hline P. polymyxa & $111.3^{\mathrm{b}}$ & $3.3^{\mathrm{b}}$ & $17.8^{\mathrm{b}}$ & $35.3^{b}$ & $77.7^{\mathrm{a}}$ & $1.390^{\mathrm{b}}$ \\
\hline Rizolex T & $119.0^{\mathrm{a}}$ & $3.9^{\mathrm{a}}$ & $18.7^{\mathrm{a}}$ & $40.8^{\mathrm{a}}$ & $79.6^{\mathrm{a}}$ & $1.540^{\mathrm{a}}$ \\
\hline Control & $90.0^{\mathrm{d}}$ & $2.4^{\mathrm{c}}$ & $13.1^{\mathrm{d}}$ & $27.1^{\mathrm{d}}$ & $69.8^{c}$ & $0.981^{\mathrm{d}}$ \\
\hline \multicolumn{7}{|c|}{$2018-2019$} \\
\hline T. viride & $106.8^{\mathrm{b}}$ & $2.9^{b}$ & $17.1^{b}$ & $32.1^{\mathrm{b}}$ & $72.6^{b}$ & $1.231^{\mathrm{c}}$ \\
\hline T. harzianum & $107.3^{b}$ & $3.0^{\mathrm{b}}$ & $16.7^{b}$ & $32.9^{b}$ & $72.9^{b}$ & $1.253 \mathrm{bc}$ \\
\hline P. flouresence & $102.1^{\mathrm{c}}$ & $2.8^{\mathrm{b}}$ & $16.6^{\mathrm{b}}$ & $31.3^{\mathrm{b}}$ & $70.2^{b}$ & $1.240^{b c}$ \\
\hline B.megaterium & $107.5^{b}$ & $2.9^{b}$ & $17.0^{\mathrm{b}}$ & $33.4^{\mathrm{b}}$ & $71.6^{\mathrm{b}}$ & $1.282^{\mathrm{b}}$ \\
\hline P. polymyxa & $109.6^{\mathrm{b}}$ & $3.1^{\mathrm{b}}$ & $17.6^{\mathrm{b}}$ & $34.2^{b}$ & $73.0^{\mathrm{b}}$ & $1.340^{\mathrm{b}}$ \\
\hline Rizolex T & $115.5^{\mathrm{a}}$ & $4.0^{\mathrm{a}}$ & $18.4^{\mathrm{a}}$ & $37.3^{\text {a }}$ & $76.4^{\mathrm{a}}$ & $1.500^{\mathrm{a}}$ \\
\hline Control & $87.2^{\mathrm{c}}$ & $2.2^{\mathrm{c}}$ & $12.9^{\mathrm{c}}$ & $25.3^{\mathrm{c}}$ & $67.2^{\mathrm{c}}$ & $0.969^{\mathrm{d}}$ \\
\hline
\end{tabular}

Values are the average of 3 experiments. Mean values (within the same column) in both seasons followed by different superscripts are significantly different at the $5 \%$ level.

All treatments significantly increased the weight of one hundred seeds in two seasons as compared with untreated control. The seed treatments with Rizolex T and P. polymyxa significantly increased the weight of one hundred seed and it differed from the rest of all treatments at 2017-2018 growing seasons. Meantime, there were no significant differences among the treatments with at 20182019 growing seasons.

The two seasons showed nearly similar seeds yield results which indicated that all treatments significantly increased the seed yield as compared with untreated control sample. The maximum seed yield was recorded from Rizolex $T$ treatment which significantly followed by $P$. polymyxa and differed from the rest of all treatments.

From the result, treatment with $P$. polymyxa, had a significant effect on damping off reduction and significantly enhanced the vegetative and seed growth parameters of Faba bean plants at field conditions compared with untreated control. Previous reports have shown that P. polymyxa controls many soil in the greenhouse and in the field (Raza et al., 2015). P. polymyxa and P. fluorescens can be produce a wide variety of antimicrobial metabolites such as the antibiotic 2,4- diacetyl phloroglucinol and pyrrolnitrin, hydrolytic enzymes from bacteria such as chitinase, $\beta-1,3$-glucanase, and protease (Zhang et al., 2016).

The Trichoderma treatment had, also, a significant effect on damping off reduction and significantly enhanced the vegetative and seed growth parameters of Faba bean plants under field conditions compared with untreated control, identified a potential Trichoderma isolate (T. viride T14) that could stimulate the growth of cucumber and bottle gourd plants and which acted as an antagonist against Sclerotium rolfsii and Rhizoctonia solani. Many T. harzianum isolates were previously found to control the development of Rhizoctonia solani of many crops under greenhouse and field conditions 
(Basak and Basak, 2011). T. harzianum was demonstrated to be very efficient producer of a wide range of extracellular enzymes and some of these were implicated in the biological control of plant diseases. Meanwhile, T. harzianum is well known producers of antibiotic (produced by some but not all strains) that are toxic for phytopathogenic fungi (Vinale et al., 2009). It could be concluded that using biocontrol agent is a promising methods for controlling damping off and root rot diseases. Soil inoculation with phosphorein, known as phosphate dissolving bacteria, has been reported to improve soil fertility and plant productivity. (Mohammed 2004).

\section{Chemical composition of Faba bean seeds}

The chemical composition of Faba bean seeds (2018-2019 seasons) treated with biocontrol agents T. viride, T. harzianum. P. fluorescens, B. megaterium, P. polymyxa and the fungicide Rizolex T are presented in Table 3. Moisture content showed significant differences among the treatments, moisture content was recorded slightly high amounts in Rizolex T and B. megaterium treatments ( 7.94 and 8.06 $\%$, respectively), while the lowest value of such content reached to $7.62 \%$ in control seeds under the same conditions. Same results agreed with Hendawey and Younes (2013).

Table 3: Effect of some chemical and biocontrol agents as seed treatments on chemical composition (\% as dry weight basis) of Faba bean seeds

\begin{tabular}{|c|c|c|c|c|c|c|c|}
\hline Sample & Moisture & Fat & Ash & $\begin{array}{c}\text { Crude } \\
\text { fiber }\end{array}$ & Protein & TC & IVPD \\
\hline T. viride & $7.70^{\mathrm{cd}} \pm 0.02$ & $2.13^{a b} \pm 0.01$ & $3.34^{b c} \pm 0.04$ & $7.09^{a} \pm 0.01$ & $29.47^{f} \pm 0.01$ & $57.97^{b} \pm 0.05$ & $52.23^{f} \pm 0.07$ \\
\hline T. harzianum & $7.77^{c} \pm 0.02$ & $2.18^{\mathrm{a}} \pm 0.01$ & $3.35^{\mathrm{bc}} \pm 0.02$ & $7.09^{\mathrm{a}} \pm 0.02$ & $29.50^{\mathrm{b}} \pm 0.01$ & $57.88^{b} \pm 0.06$ & $60.54^{\mathrm{d}} \pm 0.06$ \\
\hline P. fluorescens & $7.78^{c} \pm 0.01$ & $2.03^{\mathrm{ab}} \pm 0.13$ & $3.34^{\mathrm{bc}} \pm 0.03$ & $6.40^{\mathrm{e}} \pm 0.02$ & $30.21^{\mathrm{d}_{ \pm}} \pm 0.01$ & $58.02^{b} \pm 0.08$ & $64.30^{\mathrm{c}} \pm 0.03$ \\
\hline B. megaterium & $8.06^{\mathrm{a}} \pm 0.04$ & $1.86^{\mathrm{d}} \pm 0.05$ & $3.35^{\mathrm{bc}} \pm 0.01$ & $6.65^{\mathrm{d}} \pm 0.04$ & $30.51^{\mathrm{b}} \pm 0.04$ & $57.63^{c} \pm 0.06$ & $65.57^{\mathrm{a}} \pm 0.06$ \\
\hline P. polymyxa & $7.80^{c} \pm 0.05$ & $1.85^{\mathrm{d}} \pm 0.03$ & $3.38^{\mathrm{b}} \pm 0.03$ & $6.74^{c} \pm 0.00$ & $31.46^{\mathrm{a}} \pm 0.02$ & $56.57^{\mathrm{e}} \pm 0.08$ & $65.67^{\mathrm{a}} \pm 0.05$ \\
\hline Rizolex T & $7.94^{\mathrm{b}} \pm 0.06$ & $1.91^{\mathrm{cd}_{ \pm}} 0.13$ & $3.45^{\mathrm{a}} \pm 0.03$ & $6.96^{\mathrm{b}} \pm 0.03$ & $30.35^{\mathrm{c}} \pm 0.02$ & $57.33^{\mathrm{d}} \pm 0.07$ & $64.84^{\mathrm{b}} \pm 0.16$ \\
\hline Control & $7.62^{\mathrm{d}} \pm 0.03$ & $1.83^{\mathrm{d}} \pm 0.04$ & $3.31^{\mathrm{c}} \pm 0.01$ & $6.77^{c} \pm 0.04$ & $28.56^{\mathrm{g}} \pm 0.02$ & $59.53^{\mathrm{a}} \pm 0.12$ & $53.70^{\mathrm{e}} \pm 0.01$ \\
\hline
\end{tabular}

TC: Total carbohydrates

Values are the average of 3 experiments \pm SD. Mean values followed (within the same column) by different superscripts are significantly different at the $5 \%$ level.

The range in fiber content extended from 6.40 to $7.09 \%$ for seeds treated with $P$. fluorescens and T. harzianum or T. viride. On the other hand, treated seeds with $T$. harzianum and $T$. viride recorded the highest value of fat content, compared with the other treated seeds. The results showed that ash content ranged from 3.31 to $3.45 \%$ for seeds under study. These results agreed with Perez-Maldonado et al. (1999). Total carbohydrates of Faba bean seeds ranged from 56.57 to $59.53 \%$. There are significant differences in protein content among the total samples, wherein protein values ranged from 28.56 to $31.46 \%$ where the highest value was in P. polymyxa treatment seeds (31.46\%) followed by seeds treated with B. megaterium (30.51\%) and Rizolex T fungicide (30.35\%), while the lowest amount was $(28.56 \%)$ in control seeds. Protein content of Faba bean seeds ranged from 20.35 to $23.02 \%$, with an average of $21.73 \%$ (Yahia et al., 2013). This may be due to the biocontrol agents effect on formation of amino acids, which led to increase protein content (Agamy et al., 2012).

Biocontrol agent bacteria improved the In vitro protein digestibility (IVPD) compared with control seeds (Table 3). Non-significant differences were found between $P$. polymyxa and $B$. megaterium where recorded the highest values $(65.67$ and $65.57 \%$, respectively) followed by the fungicide Rizolex T (64.84\%) and P. fluorescens (64.30\%), then the lowest value for T. viride $(52.23 \%)$. The IVPD in Faba beans affected by many factors such as genotype and tannin contents (Osman et al. (2010).

Inoculation of Faba bean seeds with bacteria (Biocontrol agent) led to increase the availability of various nutrients that positively reflected in growth, yield and its quality (Abo El-Soud et al., 2003).

\subsection{Minerals content}

The minerals content of Faba bean seeds treated with biocontrol agents and fungicide Rizolex $T$ are shown in Table (4). Data showed significant differences in minerals content among treatments. The 
calcium and magnesium values seemed to be similar and recorded the highest values in fungicide Rizolex T and $P$. polymyxa treated seeds. The lowest value were detected in $T$. viride seeds $(982.5 \mathrm{ppm})$ for calcium and (1062.0ppm) for magnesium, while control seeds had 1042.5 and $1379.00 \mathrm{ppm}$ for calcium and magnesium, respectively.

Potassium content was abundant mineral in Faba bean seeds, with a range of 11021.0 to 13571.5 ppm where, the highest value was in case of Rizolex T treated seeds (13571.5 ppm) followed by $P$. polymyxa, B. megaterium and P. fluorescens treated seeds (13560.0, 13481.0 and $13313.0 \mathrm{ppm}$, respectively). Iron content ranged from 28.55 to $43.76 \mathrm{ppm}$, the highest values were found in $P$. polymyxa and the lowest value for $T$. viride treated seeds.

Table 4: Effect of some chemical and biocontrol agents as seed treatments on minerals (ppm) quantified (as dry weight basis) of Faba bean seeds

\begin{tabular}{llllll}
\hline Sample & $\mathbf{C a}(\mathbf{p p m})$ & $\mathbf{M g}(\mathbf{p p m})$ & $\mathbf{K}(\mathbf{p p m})$ & $\mathbf{F e}(\mathbf{p p m})$ & $\mathbf{Z n}(\mathbf{p p m})$ \\
\hline $\boldsymbol{T}$. viride & $982.5^{\mathrm{g}} \pm 2.12$ & $1062.0^{\mathrm{f}} \pm 4.24$ & $11021.0^{\mathrm{e}} \pm 1.41$ & $28.55^{\mathrm{f}} \pm 0.35$ & $22.42^{\mathrm{f}} \pm 0.11$ \\
$\boldsymbol{T}$. harzianum & $1006.5^{\mathrm{f}} \pm 3.54$ & $1186.5^{\mathrm{e}} \pm 4.95$ & $11458.5^{\mathrm{f}} \pm 4.95$ & $32.65^{\mathrm{e}} \pm 0.21$ & $24.10^{\mathrm{e}} \pm 0.14$ \\
$\boldsymbol{P}$. fluorescens & $1019.0^{\mathrm{e}} \pm 1.41$ & $1354.75^{\mathrm{d}} \pm 3.18$ & $13313.0^{\mathrm{d}} \pm 2.83$ & $34.10^{\mathrm{d}} \pm 0.01$ & $27.81^{\mathrm{c}} \pm 0.28$ \\
B. megaterium & $1027.5^{\mathrm{d}} \pm 2.12$ & $1407.5^{\mathrm{b}} \pm 6.36$ & $13481.0^{\mathrm{c}} \pm 2.83$ & $40.15^{\mathrm{b}} \pm 0.21$ & $28.90^{\mathrm{b}} \pm 0.14$ \\
$\boldsymbol{P}$ polymyxa & $1074.0^{\mathrm{b}} \pm 1.41$ & $1406.75^{\mathrm{b}} \pm 1.10$ & $13560.0^{\mathrm{b}} \pm 0.00$ & $43.76^{\mathrm{a}} \pm 0.30$ & $31.53^{\mathrm{a}} \pm 0.39$ \\
Rizolex T & $1084.2^{\mathrm{a}} \pm 0.50$ & $1427.5^{\mathrm{a}} \pm 3.54$ & $13571.5^{\mathrm{a}} \pm 2.12$ & $36.55^{\mathrm{c}} \pm 0.35$ & $27.20^{\mathrm{c}} \pm 0.28$ \\
Control & $1042.5^{\mathrm{c}} \pm 2.95$ & $1379.00^{\mathrm{c}} \pm 1.41$ & $11843.5^{\mathrm{g}} \pm 4.95$ & $34.54^{\mathrm{d}} \pm 0.35$ & $26.31^{\mathrm{d}} \pm 0.27$
\end{tabular}

Values are the average of 3 experiments \pm SD. Mean values (within the same column) followed by different superscripts are significantly different at the $5 \%$ level.

Biocontrol agents bacteria treated seeds had the highest zinc level followed by fungicide Rizolex $\mathrm{T}$ treated seeds where the highest value for P. polymyxa $(31.53 \mathrm{ppm})$ and the lowest value for $T$. viride treated seeds (22.42ppm).

Khazaei and Vandenberg (2020) found that Faba bean seeds had generous amounts of K (11315 ppm), P (5118 ppm), S (1903 ppm), Mg (1334 ppm), and Ca (971 ppm). The Fe and Zn concentrations were 51 and $42 \mathrm{ppm}$, respectively. Ray et al. (2014) found that, the low- tannin white-flowered Faba beans were rich in $\mathrm{Ca}, \mathrm{Mg}, \mathrm{Fe}$, and $\mathrm{Zn}$, which are minerals often lacking in the human diet globally. The bio-fertilizers (Bacillus megaterium) have a positive integrative roles in growing of plants by increasing available nitrogen, phosphorus, potassium and calcium (Mahdi et al., 2019).

\subsection{Phytochemicals}

Phytochemicals, especially phenolics are known to be major bioactive compounds for health benefits. Plant extracts containing different classes of polyphenols are very attractive in the food industry (Pasricha et al., 2014).

Data presented in Table (5) show the effect of some biocontrol agents as well as the fungicide (Rizolex T) on total phenolics compounds content, total flavonoids content, tannins content and antioxidant activity. Significant differences were observed among all treatments. Fungicide Rizolex T and biocontrol agent $P$. polymyxa treated seeds recorded high total phenols content [132.83 and 132.28 $\mathrm{mg}$ gallic acid equivalent (GAE)/100g respectively]. The lowest value was found in Faba bean seeds treated with $T$. viride $(125.79 \mathrm{mg} \mathrm{GAE} / 100 \mathrm{~g})$. Journi et al. (2015) found that, the value of total phenols content in the methanol extract of Faba beans were $(0.991 \mathrm{mg} \mathrm{GAE} / \mathrm{g})$. The total phenolic contents are near those mentioned by Baginsky et al. (2013) in Faba bean values ranging from $0.81 \mathrm{mg} \mathrm{GAE} / \mathrm{g}$ to $1.33 \mathrm{mg} \mathrm{GAE} / \mathrm{g}$.

Total flavonoids content showed significant differences among all treatments of Faba beans. Paenibacillus polymyxa treated seeds recorded the highest value [53.00 $\mathrm{mg}$ Quercetin equivalent $(\mathrm{QE}) / 100 \mathrm{~g}$ ], followed B. megaterium treated seeds $42.22 \mathrm{mg} \mathrm{QE} / 100 \mathrm{~g}$. The results of $P$. fluorescens treated seeds were close to those of the fungicide Rizolex T treated seeds, recording 38.21 and $38.55 \mathrm{mg}$ $\mathrm{QE} / 100 \mathrm{~g}$, respectively. The least effect was in T. viride, where treated seeds recorded $33.50 \mathrm{mg}$ QE/100g. Journi et al. (2015) found that the amount of flavonoids content was registered in Faba beans methanolic extract $(0.128 \mathrm{mg} \mathrm{QE} / \mathrm{g})$. 
Table 5: Effect of some chemical and biocontrol agents as seed treatments on phytochemical analysis of Faba bean seeds.

\begin{tabular}{lllll}
\hline Treatments & $\begin{array}{c}\text { T. phenols } \\
(\mathbf{m g} \text { GAE/100g) }\end{array}$ & $\begin{array}{c}\text { T. flavonoid } \\
(\mathbf{m g} \text { QE/100g) }\end{array}$ & $\begin{array}{c}\text { Tannins } \\
(\mathbf{m g ~ C E} / \mathbf{1 0 0 g})\end{array}$ & AOA \% \\
\hline $\boldsymbol{T}$. viride & $125.79^{\mathrm{g}} \pm 0.08$ & $33.50^{\mathrm{e}} \pm 0.14$ & $45.02^{\mathrm{a}} \pm 0.01$ & $46.82^{\mathrm{g}} \pm 0.01$ \\
$\boldsymbol{T}$. harzianum & $128.15^{\mathrm{e}} \pm 0.18$ & $35.07^{\mathrm{d}} \pm 0.05$ & $43.70^{\mathrm{b}} \pm 0.01$ & $48.91^{\mathrm{e}} \pm 0.00$ \\
$\boldsymbol{P}$. fluorescens & $129.65^{\mathrm{d}} \pm 0.10$ & $38.21^{\mathrm{c}} \pm 0.01$ & $35.42^{\mathrm{e}} \pm 0.06$ & $51.81^{\mathrm{d}} \pm 0.00$ \\
B. megaterium & $130.15^{\mathrm{c}} \pm 0.10$ & $42.22^{\mathrm{b}} \pm 0.02$ & $32.24^{\mathrm{f}} \pm 0.04$ & $53.65^{\mathrm{b}} \pm 0.04$ \\
$\boldsymbol{P}$. polymyxa & $132.28^{\mathrm{b}} \pm 0.08$ & $53.00^{\mathrm{a}} \pm 0.15$ & $32.34^{\mathrm{g}} \pm 0.10$ & $55.12^{\mathrm{a}} \pm 0.03$ \\
Rizolex T & $132.83^{\mathrm{a}} \pm 0.03$ & $38.55^{\mathrm{c}} \pm 0.21$ & $39.43^{\mathrm{d}} \pm 0.02$ & $52.22^{\mathrm{c}} \pm 0.04$ \\
Control & $126.18^{\mathrm{f}} \pm 0.06$ & $33.46^{\mathrm{e}} \pm 0.03$ & $40.39^{\mathrm{c}} \pm 0.04$ & $47.82^{\mathrm{f}} \pm 0.01$ \\
\hline
\end{tabular}

Values are the average of 3 experiments \pm SD. Mean values (within the same column) followed by different superscripts are significantly different at the 5\% level. GAE: gallic acid equivalent; QE: Quercetin equivalent CE: catechin equivalent

Trichoderma viride treatment showed the highest seed tannins content [45.02mg Catachin equivalent (CE) $/ 100 \mathrm{~g}$ ] followed $T$. harzianum where recorded $(43.70 \mathrm{mg} \mathrm{CE} / 100 \mathrm{~g})$ and the lowest value recorded in B. megaterium (32.24mg CE/100g). These results agreement with Osman et al. (2010) who found that, tannins content ranged from ( 0.041 to $0.363 \%)$.

Antioxidant activity (AOA) measured the free radical scavenging (\%) using the DPPH method. The results ranged from 46.82 to $55.12 \%$ (Table 5). The highest value was recorded in P. polymyxa bioagent compared with other treatments. Yehia et al. (2013) found that the free radical scavenging activity determined by DPPH ranged from 0.374 to $0.578 \mathrm{mM}$.

\section{Technological evaluation}

\subsection{Physical properties}

Five biocontrol agents i.e. T. viride, T. harzianum. P. fluorescens, B. megaterium, P. polymyxa and fungicide Rizolex T with a recommended dose ( $3 \mathrm{~g} / \mathrm{kg}$ seeds) were tested to study their effect on density, seeds parts (cotyledons/seed coat) and color measurements.

No significant differences were observed among biocontrol agents bacteria treated seeds. Density ranged from 1.10 to $1.27 \mathrm{~g} / \mathrm{ml}$. Rizolex $\mathrm{T}$ treatment had the highest density value $(1.27 \mathrm{~g} / \mathrm{ml})$ followed by B.megaterium and $P$. polymyxa $(1.22 \mathrm{~g} / \mathrm{ml})$, while $T$. viride had the lowest value $(1.10 \mathrm{~g} / \mathrm{ml})$. Kaur et al. (2014) found that the density of the Vicia faba seeds was $1.27 \mathrm{~g} / \mathrm{ml}$.

The ratio between cotyledons and seeds coat indicates how full the seed is. Some of the biocontrol bacteria recorded the highest value, as well as Rizolex $\mathrm{T}$ fungicide, as there were no significant differences between them. The lowest value was for control, $T$. harzianum and T. viride (7.02, 6.85 and 6.48 , respectively).

Table 6: Effect of some chemical and biocontrol agents as seed treatments on the tested physical properties of Faba bean seeds.

\begin{tabular}{llllcc}
\hline Teatments & Density & Cotyledons/ & \multicolumn{3}{c}{ Color } \\
\cline { 4 - 6 } & $(\mathbf{g} / \mathbf{m l})$ & & \multicolumn{1}{c}{$\boldsymbol{L}$} & $\boldsymbol{a}$ & $\boldsymbol{b}$ \\
\hline $\boldsymbol{T}$. viride & $1.10^{\mathrm{c}} \pm 0.03$ & $6.48^{\mathrm{d}} \pm 0.23$ & $59.90^{\mathrm{c}} \pm 0.88$ & $11.26^{\mathrm{ab}} \pm 0.78$ & $30.54^{\mathrm{a}} \pm 0.41$ \\
$\boldsymbol{T}$. harzianum & $1.18^{\mathrm{b}} \pm 0.00$ & $6.85^{\mathrm{c}} \pm 0.05$ & $60.01^{\mathrm{c}} \pm 1.05$ & $9.74^{\mathrm{c}} \pm 0.44$ & $30.62^{\mathrm{a}} \pm 0.36$ \\
$\boldsymbol{P}$. fluorescens & $1.17^{\mathrm{bc}} \pm 0.01$ & $7.10^{\mathrm{ab}} \pm 0.01$ & $64.75^{\mathrm{b}} \pm 0.43$ & $12.41^{\mathrm{a}} \pm 0.73$ & $30.81^{\mathrm{a}} \pm 0.53$ \\
B.megaterium & $1.22^{\mathrm{ab}} \pm 0.01$ & $7.16^{\mathrm{ab}} \pm 0.06$ & $65.74^{\mathrm{ab}} \pm 0.43$ & $9.33^{\mathrm{c}} \pm 0.49$ & $30.06^{\mathrm{a}} \pm 0.74$ \\
$\boldsymbol{P}$. polymyxa & $1.22^{\mathrm{ab}} \pm 0.00$ & $7.26^{\mathrm{a}} \pm 0.05$ & $66.31^{\mathrm{a}} \pm 0.71$ & $8.62^{\mathrm{c}} \pm 0.61$ & $26.73^{\mathrm{b}} \pm 0.40$ \\
Rizolex T & $1.27^{\mathrm{a}} \pm 0.06$ & $7.20^{\mathrm{ab}} \pm 0.03$ & $65.05^{\mathrm{ab}} \pm 0.55$ & $8.67^{\mathrm{c}} \pm 1.10$ & $30.46^{\mathrm{a}} \pm 0.23$ \\
Control & $1.16^{\mathrm{bc}} \pm 0.01$ & $7.02^{\mathrm{bc}} \pm 0.01$ & $64.70^{\mathrm{b}} \pm 0.73$ & $10.02^{\mathrm{bc}} \pm 0.56$ & $30.69^{\mathrm{a}} \pm 0.24$ \\
\hline
\end{tabular}

Values are the average of 3 experiments \pm SD. Mean values (within the same column) followed by different superscripts are significantly different at the $5 \%$ level.

The effect of different biocontrol agents and the fungicide Rizolex $\mathrm{T}$ on color measurements of Faba beans noticed that, the highest lightness values were in Faba bean seeds treated with biocontrol $P$. polymyxa and B. megaterium followed by the fungicide Rizolex T (66.31, 65.74 and 65.05 respectively). 
The lowest values were recorded in Faba bean seeds treated with biocontrol T. viride (59.90). In addition, increase in the redness values $(a)$ and yellowness $(b)$ values showed in Faba bean seeds treated with $T$. viride biocontrol agent than other treatments and control. Abdel-Aleem et al. (2019) found that, color parameters of Faba bean seeds $L, a$ and $b$ recorded 82.86, 6.27 and 8.07 respectively.

\subsection{Water absorption, hydration and swelling coefficients of Faba bean treated seeds.}

The results of water absorption of Faba bean seeds after soaking and after cooking are shown in Fig 1. The results showed that, high value of water absorption after soaking recorded for $P$. polymyxa, B. megaterium and Rizolex T treatments (116.03, 115.98 and $115.21 \%)$, respectively, compared with control (106.93\%). The corresponding values after cooking were 159.57, 158.87 and $155.16 \%$, respectively, compared with control (140.92\%). Abdel-Aleem et al. (2019) reported that, water absorption of Faba bean seeds was $144.30 \%$ after cooking as compared with $84.35 \%$ after soaking.

Fig. 2 presents the hydration coefficient of Faba bean seeds after soaking and after cooking. Biocontrol agents $P$. polymyxa, B. megaterium treated seeds showed the highest value for soaking (210.54 and 209.67\%). Hydration coefficient of Faba bean seeds after cooking takes the same trend of absorbing water compared with control. Where the high value was recorded in $P$. polymyxa, $B$. megaterium and Rizolex T $(260.84,258.07$ and $249.61 \%$ respectively) compared with control (240.94\%). Abdel-Aleem et al. (2019) revealed that hydration coefficient increased after cooking and ranged from 220.47 to $257.10 \%$.

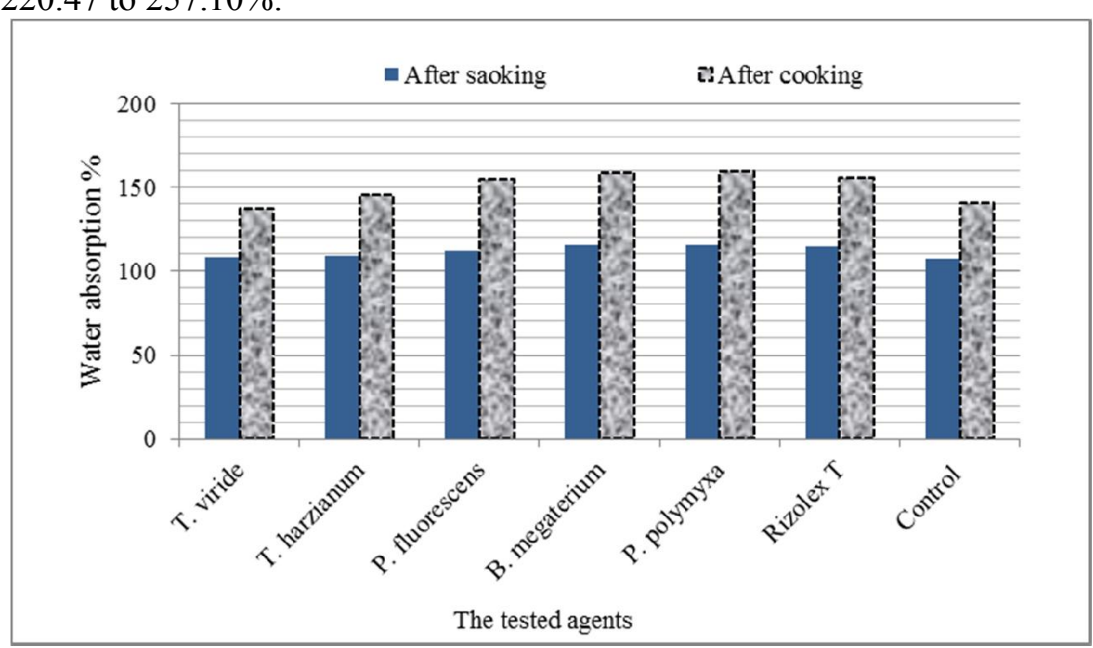

Fig. 1: Effect of some chemical and biocontrol agents as seed treatments on water absorption after soaking and cooking of Faba bean seeds.

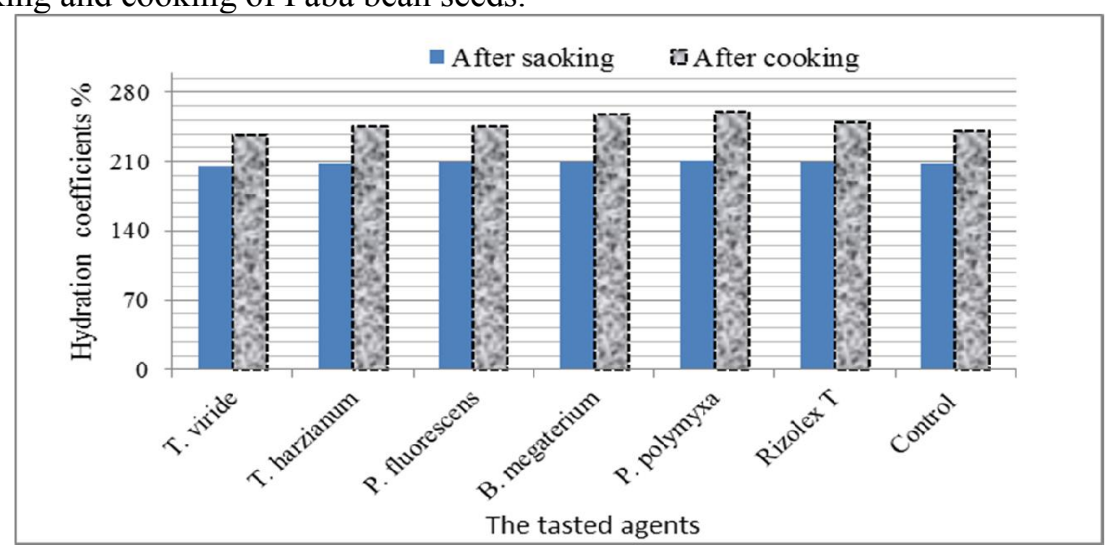

Fig. 2: Effect of some chemical and biocontrol agents as seed treatments on hydration coefficients after soaking and cooking of Faba bean seeds. 


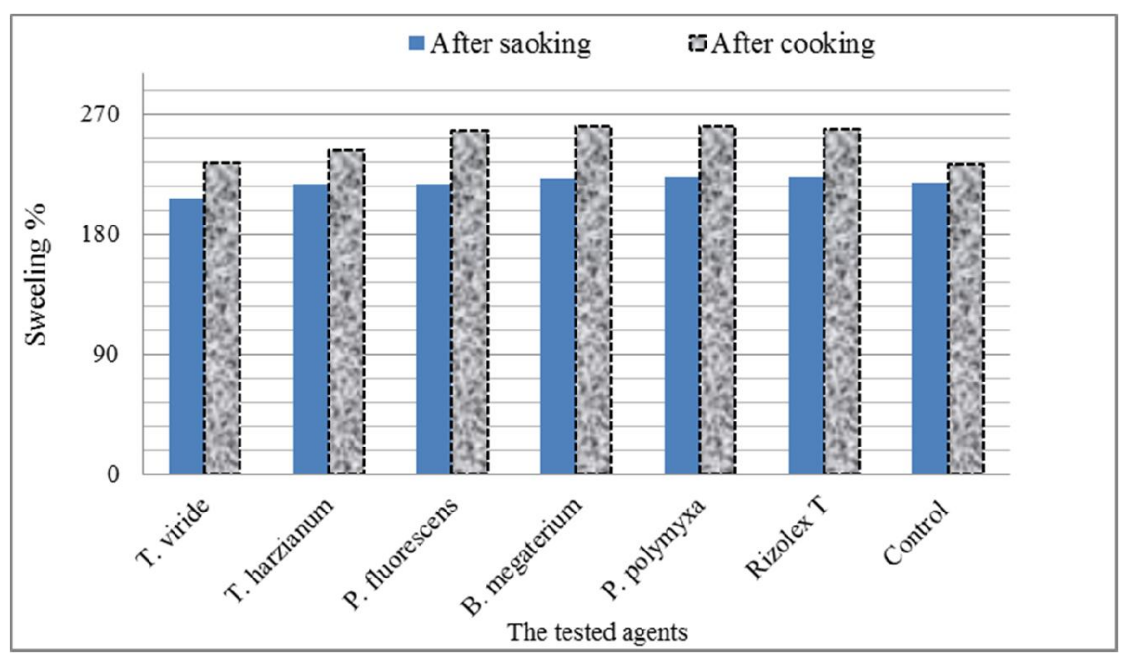

Fig. 3: Effect of some chemical and biocontrol agents as seed treatments on swelling coefficients after soaking and cooking of Faba bean seeds.

Swelling coefficients of Faba bean treated seeds are shown in Fig 3. P. polymyxa, B. megaterium and Rizolex T treatments seeds had the high values of swelling coefficients after soaking and after cooking compared with other treatments.

The hydration and swelling coefficients reflect the capacity to absorb water during soaking process. Both consumers and processors prefer beans that have high hydration and swelling coefficients as these produce greater quantity with better quality (Nasar-Abbasa et al., 2008).

\section{Cooking quality}

Effect of treated Fabe bean seeds with biocontrol agents (bacteria and fungi) and fungicide Rizolex T on cooking quality of Faba bean treated seeds are shown in Table (7). Regarding to stewing percent, the highest value recognized in biocontrol agents bacteria $P$. polymyxa treatment (100\%), no significant differences were obtained among $P$. fluorescens, $B$. megaterium, and fungicide Rizolex $\mathrm{T}$ (98.67, 98.33 and $98.21 \%$, respectively). Significant differences were observed among control and other treatments. In general biocontrol agents treatments (bacteria) and fungicide Rizolex T improved stewing character compared with control and $P$. polymyxa treatment was the best treatment.

Total soluble solids (TSS), showed the highest values in $P$. fluorescens, $B$. megaterium and $P$. polymyxa treatments $(9.86,9.78$, and $9.77 \%$, respectively) where no significant differences were found among them, followed by Rizolex $\mathrm{T}$ and control (9.59 and 9.31\%). T. harzianum and T viride treatments had the lowest TSS values (8.84 and $8.47 \%$, respectively).

Table 7: Effect of some chemical and biocontrol agents as seed treatments on the percentage of cooking quality and total soluble solids of Faba bean seeds

\begin{tabular}{lll}
\hline Treatments & Stewing \% & TSS \% \\
\hline T. viride & $82.32^{\mathrm{e}} 0.00$ & $8.47^{\mathrm{e}} \pm 0.23$ \\
T. harzianum & $85.00^{\mathrm{d}} \pm 0.00$ & $8.84^{\mathrm{d}} \pm 0.07$ \\
$\boldsymbol{P}$. fluorescens & $98.67^{\mathrm{b}} \pm 0.58$ & $9.86^{\mathrm{a}} \pm 0.07$ \\
B. megaterium & $98.33^{\mathrm{b}} \pm 1.15$ & $9.78^{\mathrm{a}} \pm 0.04$ \\
$\boldsymbol{P}$ polymyxa & $100.00^{\mathrm{a}} \pm 0.00$ & $9.77^{\mathrm{a}} \pm 0.01$ \\
Rizolex T & $98.21^{\mathrm{b}} \pm 1.15$ & $9.59^{\mathrm{b}} \pm 0.06$ \\
Control & $89.33^{\mathrm{c}} \pm 1.15$ & $9.31^{\mathrm{c}} \pm 0.04$ \\
\hline Valrol
\end{tabular}

Values are the average of 3 experiments \pm SD. Mean values (within the same column) followed by different superscripts are significantly different at the $5 \%$ level.

\section{Sensory characteristics of cooked Faba bean seeds}

Sensory evaluation for color, texture, taste, odor and overall acceptability (OAA) of the cooked Faba bean seeds as influenced by biocontrol agent and Rizolix $\mathrm{T}$ fungicide were done in order to determine consumer acceptability (Table 8). The results revealed an increase in color value in the 
sample treated with $P$. polymyxa, B. megaterium and Rizolex T (9.1, 9.00 and 8.65\%, respectively), followed by $P$. fluorescens $(8.4 \%)$. and the lowest value was in $T$. viride treatment $(7.3 \%)$. No significant differences were observed in odor among all samples. The same trend was observed in taste at all treatments except $T$. viride. Over all acceptability recorded low value in $T$. Viride seeds treatment. It could be seen that Faba beans which treated with biocontrol bacteria and Rizolix $T$ fungicide recorded the highest sensory quality in terms of color, texture, taste, odor and overall acceptability followed by T. harzianum and control. On the other hand, Abdel-Aleem et al. (2019) showed that, sensory quality of Faba bean seeds were recorded color $(50 \%)$, texture $(50 \%)$, taste $(60 \%)$, odor $(60 \%)$ and overall acceptability $(50 \%)$.

Table 8: Sensory characteristics of cooked Faba bean seeds treated with chemical and biocontrol agents

\begin{tabular}{llllll}
\hline Treatments & Color & Texture & Taste & Odor & OAA \\
\hline T. viride & $7.3^{\mathrm{d}} \pm 0.67$ & $6.9^{\mathrm{e}} \pm 0.88$ & $7.7^{\mathrm{b}} \pm 0.82$ & $8.8 \mathrm{a} \pm 0.92$ & $6.95^{\mathrm{e}} \pm 0.60$ \\
$\boldsymbol{T}$. harzianum & $7.9^{\mathrm{c}} \pm 0.74$ & $7.8^{\mathrm{c}} \pm 0.63$ & $9.1^{\mathrm{a}} \pm 0.88$ & $8.9 \mathrm{a} \pm 0.74$ & $7.7^{\mathrm{cd}} \pm 0.95$ \\
$\boldsymbol{P}$. fluorescens & $8.4^{\mathrm{bc}} \pm 0.70$ & $8.1 \mathrm{c} \pm 0.57$ & $8.6^{\mathrm{a}} \pm 1.17$ & $9.0 \mathrm{a} \pm 0.94$ & $7.95^{\mathrm{bc}} \pm 0.76$ \\
B. megaterium & $9.00^{\mathrm{a}} \pm 0.67$ & $8.9^{\mathrm{b}} \pm 0.99$ & $9.1^{\mathrm{a}} \pm 0.88$ & $9.3 \mathrm{a} \pm 0.48$ & $8.5^{\mathrm{ab}} \pm 0.53$ \\
$\boldsymbol{P}$. polymyxa & $9.1^{\mathrm{a}} \pm 0.52$ & $9.2^{\mathrm{a}} \pm 0.50$ & $8.9^{\mathrm{a}} \pm 0.74$ & $9.3 \mathrm{a} \pm 0.67$ & $8.7^{\mathrm{a}} \pm 0.48$ \\
Rizolex T & $8.65^{\mathrm{ab}} \pm 0.47$ & $8.7 \mathrm{~b} \pm 0.82$ & $8.9^{\mathrm{a}} \pm 0.88$ & $9.2 \mathrm{a} \pm 0.79$ & $8.45^{\mathrm{ab}} \pm 0.60$ \\
Control & $8.45^{\mathrm{b}} \pm 0.50$ & $7.3^{\mathrm{dc}} \pm 0.67$ & $9.1^{\mathrm{a}} \pm 0.99$ & $9.0^{\mathrm{a}} \pm 0.82$ & $7.1^{\mathrm{de}} \pm 0.74$ \\
\hline
\end{tabular}

Values are the average of 10 experiments \pm SD. Mean values (within the same column) followed by different superscripts are significantly different at the $5 \%$ level. OAA: Overall acceptability

\section{Conclusion}

All the tested biocontrol agents $P$. fluorescens, B. megaterium and P. polymyxa T. hazianum and T. viride, as well as, the chemical fungicide namely Rizolex $\mathrm{T}$ were used and significantly reduced damping off were detected. High reduction was observed in Rizolix T fungicide $P$. polymyxa, $B$. megaterium and compared with control. They, also, caused the increasing in the yield and 100 seeds weight. Quality parameters, also, were improved by using Rizolix T fungicide, P. polymyxa and $B$. megaterium. Protein content, protein digestibility and minerals contents, as well as, total phenols, total flavonoids and antioxidant activity were increased. Technological evaluation of density, ratio between cotyledons and seed coats as well as water absorption, hydration coefficients and swelling coefficients after soaking and cooking showed high values in Faba bean seeds treated with $P$. polymyxa, $B$. megaterium followed by Rizolex T. They, also, improved the cook ability, and increase the sensory evaluation parameters. Therefore, it could be concluded that the inoculation of Faba bean seeds with bacteria increase the availability of nutrients which affect the yield and quality of seeds.

\section{References}

Abdel-Aleem, W.M., S.M. Abdel-Hameed and S.S. Latif, 2019. Effect of soaking and cooking on nutritional and quality properties of Faba bean. J. Food Dairy Sci., 10(10):389-395.

Abo El-Soud, A.A., A.A. Ragab, G.A.A. Mekhemar and F.T. Mikhaeel, 2003. Response of faba bean to inoculation with $\mathrm{N}$-fixers and phosphate dissolving bacteria as influenced by different sources of phosphorus. Egypt. J. App. Sci., 18(1):73-90.

Agamy, R.A., G.F. Mohamed and M.M. Rady, 2012. Influence of the application of fertilizer type on growth, yield, anatomical structure and some chemical components of wheat (Triticum aestivum L.) grown in newly reclaimed soil. Austral. J. bas. Appl. Sci., 6(3):561-570.

Akeson, W.R. and M.A. Stahmann, 1964. Pepsin Pancreatin digest index of protein quality evaluation. J. Nutr., 83: 257-261.

AOAC., 2012. Official Methods of Analysis of Association of Official Analytical Chemists International. 19 ${ }^{\text {th }}$ Ed. Association of Official Analytical Chemists. (Ed. Latimer, G. W.), Washington, DC, USA.

Atwa, M.A.M., 2016. Induction of resistance against damping off and root rot diseases in faba bean. Arab Univ. J. Agric. Sci., 24(2): 555-578. 
Avila, B.P., M.S. Santos, A.M. Nicoletti, G.D. Alves, M.C. Elias, J. Monks and M.A. Gularte, 2015. Impact of different salts in soaking water on the cooking time, texture and physical parameters of cowpeas. Plant Foods Hum. Nutr., 70: 463-469.

Baginsky, C., A. Pena-Neira, A. Caceres, T. Hernandez, I. Estrella, H. Morales, and R. Pertuze, 2013. Phenolic compound composition in immature seeds of Fava bean (Vicia faba L.) varieties cultivated in Chile. J. Food Composition Anal., 31: 1-6.

Barłóg, P., W. Grzebisz and R. Łukowiak 2018. Faba bean yield and growth dynamics in response to soil potassium availability and sulfur application. Field Crops Res., 219: 87-97.

Basak, A.C. and S.R. Basak, 2011. Biological control of Fusarium solani f. sp. dalbergiae, the wilt pathogen of Dalbergia sissoo, by Trichoderma viride and T. harzianum. J. Tropic. Forest Sci., 23:460-466.

Bhattacharya, A., P. Sood and V. Citovsk, 2010. The roles of plant phenolics in defence and communication during Agrobacterium and Rhizobium infection. Mole. Plant Path., 11(5): $705-$ 719.

Boudet, A., 2007. Evolution and current status of research in phenolic compounds. Phytochemistry, 68: 2722-2735.

Boukhanouf, S., H. Louaileche and D. Perrin, 2016. Phytochemical content and in vitro antioxidant activity of Faba bean (Vicia faba L.) as affected by maturity stage and cooking practice. Inter. Food Res. J., 23: 954-961.

Brand-Williams, W., M.E. Cuvelier and C. Berset, 1995. Use of a free radical method to evaluate antioxidant activity . LWT-Food Sci.Tech., 28: 25-30.

El-Refai, A.A., H.M. Harras, K.M. El-Nemr, and M.A. Noaman, 1988. Chemical and technological studies on faba bean seeds. I. Effect of storage on some physical and chemical properties. Food Chem., 29: 27-39.

Fahmy, H.H., S. Sirvastava and M.A. Velerrax, 1996. Physical and textural characteristics of soaked and cooked American beans. Egypt. J. Food Sci., 24 (2): 105-118.

He, Z., D. Kisla, L. Zhang, C.H. Yuan, K.B. Green-Church, and A.E. Yousef, 2007. Isolation and identification of a Paenibacillus polymyxa strain that coproduces a novel lantibiotic and polymyxin. Appl. Environ. Microbiol., 73: 168-178.

Hendawey, M.H. and A.M.A. Younes, 2013. Biochemical evaluation of some Faba bean cultivars under rainfed conditions at El-Sheikh Zuwayid. Annals of Agric.Sci., 58 (2): 183-193.

Horoszkiewicz-Janka, J., E. Jajor and M. Korbas, 2013. Potential risk of infection of pathogenic fungi to legumes (Fabales) and possibilities of their control. Prog. Plant Protect., 53: 762-767.

Ismail, A. I., M.A. Mohamed, M.M. Mazen and K.M.M. Morsy, 2007. Influence of biotic and abiotic inducers on chocolate spot disease of Faba bean yield as well as some crop and technological parameters. Egypt. J. Appl. Sci., 22(10): 403-420.

Journi, M., H. Hammouda, M. Trabelsi-Ayadi and J.K. Chérif, 2015. Quantitative determination and identification of phenolic compounds of three Tunisian legumes: Vicia faba, Lens culinaris and Phaseolus vulgaris. Adv. Chemist. Biochemist. Sci., 2 (3): 01-12.

Jung, W.J., K.N. An, Y.L. Jin, R.D. Park, K.T. Lim, K.Y. Kim and T.H. Kim, 2003. Biological control of damping off caused by Rhizoctonia solani using chitinase producing Paenibacillus illinoisensis KJA-424. Soil Biol. Biochem., 35:1261-1264.

Kaur, S., R.B. Kimber, N.O. Cogan, M. Materne, J.W. Forster, and J.G. Paull, 2014. SNP discovery and high-density genetic mapping in Faba bean (Vicia faba L.) permits identification of QTLs for ascochyta blight resistance. Plant Sci., 217: 47-55.

Khazaei, H. and A. Vandenberg, 2020. Seed Mineral Composition and Protein Content of Faba Beans (Vicia faba L.) with Contrasting Tannin Contents. Agronomy, 10: 511-521.

Larmond, E., 1977. Laboratory methods for sensory evaluation of food. Canadian Government Publishing Center, Ottawa, Canada.

Luo, Y. and W. Xie, 2014. Effect of soaking and sprouting on iron and zinc availability in green and white Faba bean (Vicia faba L.). J. Food Sci. Technol., 51: 3970-3976.

Mahdi, A.H.A., M.M. Rady and G.A. Abd El-Wahed, 2019. Integrative application of phosphorein and microbein improves Vicia faba (L.) performance and controls soil-borne diseases. Int. J. Cur. Micro. App. Sci., 8(10): 103-121. 
Mohammed, S.S., 2004. Integrated approach for rock phosphate sulfur combined with bio fertilization in sandy loam soil. Egypt. J. Appl. Sci., 19 (2): 316-333.

Multari, S., D. Stewart, and W.R. Russell, 2015. Potential of Fava bean as future protein supply to partially replace meat intake in the human diet. Comp. Rev. in Food Sci. Food Safe, 14: 511522.

Nasar-Abbasa, S.M., J.A. Plummera, K.H.M. Siddique, P. White, D. Harris, and K. Dods, 2008. Cooking quality of Faba bean after storage at a high temperature and the role of lignins and other phenolics in bean hardening. LWT- Food Sci. Technol., 41: 1260-1267.

O'Callaghan, M., 2016. Microbial inoculation of seed for improved crop performance: issues and opportunities. Appl. Micro. Biotech., 100: 5729-5746

Osman, A.G., F.I. Abd Elaziz and G.A. ElHassan, 2010. Effects of biological and mineral fertilization on yield, chemical composition and physical characteristics of Faba bean (Vicia faba L.) cultivar. Pakis. J. Nut., 9(7): 703-708.

Pasricha, V., G. Satpathy, and R.K. Gupta, 2014. Phytochemical and Antioxidant activity of underutilized legume Vicia faba seeds and formulation of its fortified biscuits. J. Pharm. Ph., 3 (2):75-80.

Perez-Maldonado, R.A. and P.F. Mannion and D.J. Farrell, 1999. Optimum inclusion of field peas, Faba beans, chick peas and sweet lupins in poultry diets. I. Chemical composition and layer experiments. Brit. Po. Sci., 40: 667-673.

Price, M.L., V.C. Scoyoc and L.O. Butler, 1978. A critical evaluation of vanillin reaction as an assay for tannin in sorghum grain. J. Agric. Food Chem., 26: 1214-1248

Ray, H., K. Bett, B. Tar'an, A. Vandenberg, D. Thavarajah, and T. Warkentin, 2014. Mineral micronutrient content of cultivars of field pea, chickpea, common bean, and lentil grown in Saskatchewan. Canada. Crop Sci., 54: 1698-1708.

Raza, W., J. Yuan, N. Ling, Q. Huang and Q. Shen, 2015. Production of volatile organic compounds by an antagonistic strain Paenibacillus polymyxa WR2 in the presence of root exudates and organic fertilizer and their antifungal activity against Fusarium oxysporum f. sp. niveum. Biologic. Contr., 80: 89-95.

Raza, W., X.M. Yang, H.S. Wu, Y. Wang, Y.C. Xu and Q.R. Shen, 2009. Isolation and characterization of fusaricidin-type compound producing strain of Paenibacillus polymyxa SQR-21 active against Fusarium oxysporum f. sp. nevium. Eur. J. Plant Path., 125: 471-483.

Rifai, M.A., 1969. A Revision of The Genus Trichoderma. Mycological paper, 116: 56. Commonwealth Mycological Institute, Kew, Surrey, England.

Rini, C.R. and K.K. Sulochana, 2007. Substrate evaluation for multiplication of Trichoderma spp. J. Tropic. Agric., 45: 58-60.

Robinson, G.H.J., J. Balk and C. Domoney, 2019. Improving pulse crops as a source of protein, starch and micronutrients. Nutr. Bull., 44: 202-215.

Sharma, P., and S.K. Sain, 2004. Induction of systemic resistance in tomato and cauliflower by Trichoderma spp. against stalk rot pathogen, Sclerotinia sclerotiorum Lib de Bary. J. Biol. Control, 18: 21-27.

Shehata, S.T., M.M. Mosbah and M.F. Hegazi, 2006. Selection of biocontrol agents for control of onion white rot disease. J. Agric. Sci. Mansoura Univ., 31: 2621-2637.

Siah, S., J.A. Wood, S. Agboola, I. Konczak and C.L. Blanchar, 2014. Effects of soaking, boiling and autoclaving on the phenolic contents and antioxidant activities of Faba beans (Vicia faba L.) differing in seed coat colours. Food Chem., 142: 461- 468.

Silva, F.A.S. and C.A.V. Azevedo, 2009. Principal Components Analysis in the Software AssistatStatistical Attendance. In: World Congress on Computers in Agriculture, 7, Reno-NV-USA: American Society of Agricultural and Biological Engineers.

Singleton, V.L. and J.A. Rossi, 1965. Colorimetry of total phenolics with phosphomolybdicphosphotungstic acid reagents. Am. J. Enol. Vitic., 16: 144-158.

Steel, R.G. and T.H. Torrie, 1980. Principles and procedures of statistics. Abiometrical approach. McGraw Hill Book Comp., Inc., New York, USA.

Tewari, L. and C. Bhanu, 2004. Evaluation of agro-industrial wastes for conidia based inoculum production of bio-control agent: Trichoderma harzianum. J. Scient. Indus. Res., 63: 807-812. 
Tungmunnithum, D., A. Areeya Thongboonyou, A. Pholboon, and A. Yangsabai, 2018. Flavonoids and other phenolic compounds from medicinal plants for pharmaceutical and medical aspects: an overview. Medicines, 5: 93-109.

Vinale, F., G. Flematti, K. Sivasithamparam, M. Lorito, , R. Marra, , B.W. Skelton, and E.L. Ghisalberti, 2009. Harzianic acid, an antifungal and plant growth promoting metabolite from Trichoderma harzianum. J. Nat. Prod., 72: 2032-2035.

Walters, D.R., J. Ratsep, and N.D. Havis, 2013. Controlling crop diseases using induced resistance: challenges for the future. J. Exp. Bot., 64: 1263-1280.

White, P.J. and M.R. Broadley, 2009. Biofortification of crops with seven mineral elements often lacking in human diets-iron, zinc, copper, calcium, magnesium, selenium and iodine. New Phytol., 182: 49-84.

Yahia, Y., W. Elfalleh, N. Tlili, H. Hannachi, M. Loumerem, and A. Ferchichi, 2013. Phytochemical contents and antioxidant activities of some Tunisian faba bean populations. Romanian Agric. Res., 30: 65-74.

Zhang, Q., Y. Ji, Q. Xiao, S. Chng, Y. Tong, X. Chen, and F. Liu, 2016. Role of vfr in the regulation of antifungal compound production by Pseudomonas fluorescens FD6. Micro. Res., 188-189: 106-112.

Zhishen, J., T. Mengcheng, and W. Jianming, 1999. The determination of flavonoid contents in mulberry and their scavenging effects on superoxides radicals. Food Chem., 64: 555-559. 